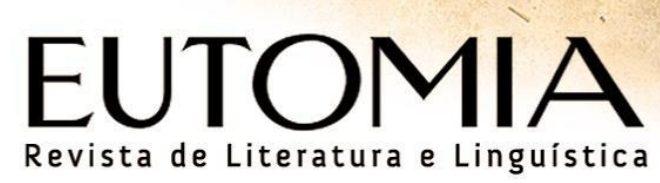

\title{
SÓIS \\ O Livro da Insônia
}

Ricardo Carranza ${ }^{\mathrm{i}}$

... na vida psíquica nada do que uma vez se formou pode perecer...

Freud

Da insônia reserva sóis de matizada angústia.

A lágrima,

oleosa do ontem

leva aos olhos

exaustos

do amanhã.

Dajanela vê

como aderna

a imensa barca

roída de sol.

De posse

do campo de

alvura

labora

a divina

Eutomia, Recife, 26(1): 380- 410, Dez. 2020 
grandeza do grão.

Eutomia, Recife, 26(1): 380- 410, Dez. 2020 
Ó rosa, corrosiva rosa.

Do sol da noite prospera teu perfume. A distância

é lente da tua exuberante ausência. A forja do silêncio é o teu segredo ó rosa, ó corrosiva. 
$\mathrm{Na}$ escrita in vitro banhado de estanho, sóis negros estreitam cosmos um como eu em beleza e destino. 
Estrelas tácitas explodem no meu caos interior.

\author{
Meus pés \\ repousam \\ no doce, \\ escuro, \\ frio \\ anseio da terra; \\ meus olhos \\ pousam \\ na verdura \\ escura \\ de sol; \\ e eu me sussurro - \\ lúcida luz, \\ sombra não é medo,
}

sementes frutificam sol enraízam noite renascem na lavra da insônia.

Eutomia, Recife, 26(1): 380- 410, Dez. 2020 
Minhas cicatrizes eternas sangram à sombra do sol negro coagulam.

Tudo recai sobre mim: soco, náusea, farpa.

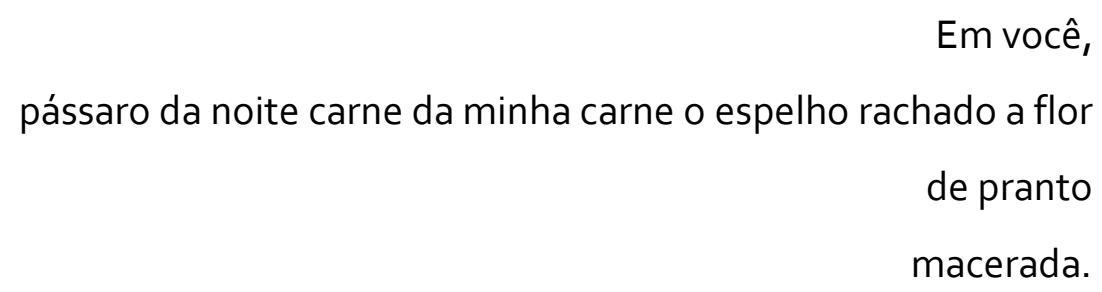

Tudo encarde, recrudesce, arde.

Por você

a palavra clara,

o riso

claro bálsamo

com que brindamos

a frágil

alegria

de viver.

Eutomia, Recife, 26(1): 380- 410, Dez. 2020 
Respiro na áspera encosta do dia a coisa que falta que sempre falta, milagre: o velho realimenta o fogo do encarnado ensaio.

Anoiteço gênio pétala lanterna sobrevivente de um dia remorso remoto repasso pássaro furta-cor músico de ruídos. 
Em mim, sangrias de renascentes gotas à luz do sol da noite.

(A sobrevivência não é anfitriã muito delicada.)

Ensaio vozes ecos da minha origem: - Eu sou a luz do mundo!

\author{
Na calçada de casa, \\ ofereço \\ meu inocente rosto \\ ao mundo. \\ Bom dia! \\ Como vai! \\ Tudo bem? \\ Graças a Deus!
}


Macho e fêmea depois de cortinas fechadas prioritariamente.

Nas sombras da tarde, o féretro meio comovido, meio aliviado, meio olhando as horas.

E o gozo é trégua, a divina trégua. 
Da janela

vejo a floração, ano após ano glaciais estrelas vermelhas indiferentes às sutilezas de um único dia. 
O primeiro olhar através da gaze pés apalpam imprecisos a morte da inocência enquanto deuses exalam ambrosia. 
Noite semeada de estrelas a giz na calçada.

E uma fala - Prazer revê-la.

Noite após noite de sol, recupero as mãos impregnadas do estranho perfume nas águas imaculadas da solidão:

Poesia é lágrima no abismo de dentro. 
Caminho no paraíso do momento: verde-petróleo, prata-brilhante, mate, sépia, rosa-chá, amarelo-pálido, amarelo-limão, ocre amarelo, ocre vermelho, nervuras de sol alaranjado.

Ofuscado pela riqueza, entro no chiado do arvoredo, no arrastar de pés no cascalho, nos rumores da vida distante. E a voz aguda de criança minha um dia arranham meu ser invisível.

Iluminado, colho a folha oxidada de sol: verde lembrança. 
Por que reter a seiva vermelha à folha branca de celulose e ausência?

Por que não alavancar o futuro no artifício da queda do brasonado orgulho?

Tomo fôlego. Reergo-me deus poético e mortal. Aspiro o tânico ar da chuva. 
Coração ligado ao estômago confronto a palavra mordente:

flor

infeccionada da infância

impõe

o refluxo do passado:

acidez, queimação, susto, desespero:

o inferno não me é estranho. 
Noite, víscera noite.

Sol negro, chiado

de brasas molhadas, quartos familiares a hálito de estômago.

Quantas eternidades, quanta claustrofobia até a razão de oscilante outono? Saciado de luz, celebro o desprezo ao sangue. 
O que vale a pena sem os ornamentos da salvação?

\author{
Entre vitrines, \\ salas de veludo, \\ o espanto do cristal estilhaçado: \\ - Tu vendeste o Cristo! \\ - Tu incendiaste Roma!
}

Na incomensurável luz

da solidão,

pequenas coisas são a divindade:

bichinho de estimação, florzinha na relva, figo nevado de açúcar. 
Gema esmeralda ossos dourados oceano branco azul.

O tempo

que drena como água nas estrias dos meus dedos, que adensa dunas, desidrata flores, devora o peixe e ostenta a espinha,

lambe os meus pés em ondas de espuma.

Do azul anil sequestro infância, a lenta brancura de nuvens, a linha luzente do areal.

A mulher, mar na borda do seio, larga os braços à rebentação.

A gaivota zap! investe um arco

prateado de sol.

Eu mal respiro.

Sigo caminho - 
não tenho abrigo, afinado ao zumbido de moscas e abelhas. A luz modela corpos recorta a pedra carrega o estouro grave da rebentação.

Da mesa ao lado, a voz se arrasta.

- Leu o Quarteto de Durrell?

Rosto escavado no tempo se ergue altivo ao meu olhar reflexivo. - Não - disse ao sol da sua morte. - Eu já! - disse em luciferino sopro raspado.

Na borda do assoalho a espuma do mar salta.

Durrell Lúcifer estouro do mar, hoje gota de tinta no papel. 
Fogueira cadeiras na calçada conversas a meia voz cortina entreaberta homem entre as coxas da mulher grito retido na garganta.

Rosto amassado dentes de âmbar corpo gasto de água e sol.

Meu nome salta em voz de suplício -

Ricardo!

Sete vezes

sete pecados capitais

entre quatro

paredes mudas.

Abelhas zumbindo

no beiral da casa.

A velha senhora

enxuga as mãos no avental manchado desalinhado esfiapado

- Não mexam na casa da abelha.

Crianças, aos gritos, correm pela rua.

O velho senhor curtido a cigarro

- Na noite de ventania - babau! - o diabo levou o menino.

- Não! - grito aterrorizado.

O trio sobe a rua em fila indiana:

filha,

mãe-solteira,

pai-avô.

Eutomia, Recife, 26(1): 380- 410, Dez. 2020 
(O pai-avô morre antes de ver a filha decapitada num desastre, a mãe-solteira fica pra desfiar seu rosário.)

A veneziana

do quarto da mãe do filho idiota

bate com o vento:

uma lasca de madeira explode

feito vaso de vidro na calçada.

O vento espalha as cinzas do incêndio. 
Cinge meus olhos reversos a desidratada folha na noite escura fria de inverno arde fibra de sol chuva no campo verde vermelho chuva na telhas carcomida de musgo chuva na porta caindo aos pedaços cheia de trancas chuva na fogueira de içás vivos chuva na ladainha pavorosa da viúva chuva na velhinha dedicada ao buquê de miudinhas folhinhas de mato chuva no pequeno caralho entre as pernas duro de ferro escondido de Deus corte na escada sangue corte voz de materno suplício tarde azul longe o vento no eucaliptal corte mais longe o acalanto envolve todo o meu corpo corte ai! meus olhos noite escura de sol. 
Aceito do dia a noite insone como o sono do amanhã.

Mãos de rosa tocam o sonho flor da pele do instinto.

No óleo do ontem unto a partícula cadente de insônia.

Deus eternamente humano, dou cor ao pássaro perfumado da terra molhada.

Suscetível como a cambraia, o mundo ilumino. 
Uma dor

desperta comigo

à luz do sol insone.

Reconheço a vertigem,

velha companheira.

Ousaria... decapitá-la?

Cortar de vez sua presença?

Elevaria

meu ínfimo sopro

acima

da tirania do tempo?

Em minhas mãos

o pássaro sombrio,

a respiração,

o calor animal.

Em quietude, em febre de sonho, passamos a noite irmanados.

O amanhecer

é a hora do adeus:

o sol

apaga o mundo.

Em mim a luz

Eutomia, Recife, 26(1): 380- 410, Dez. 2020 
da noite insone.

Eutomia, Recife, 26(1): 380- 410, Dez. 2020 
Minha pálpebra animal se abre ao silente drama em que sou plateia ator - carne vermelha embrulhada em jornal, coroa de papel em chamas, vênus salpicada de pólen, deus travestido de homem.

De minha voz interior palpita, gutural e rouca - Somos mais tubérculos que pássaros! (Porque a queda nos humaniza.)

De manhã um sol protocolar incita o vão combate. 
Janelas

azul celeste, violeta,

amarelo sódio, rosa bebe, rosa encarnado, branco marfim.

Janelas em busca de coragem, esperança, eternidade.

Pétalas de luz passo da noite adormecem. Minha janela apaga, adormeço.

Ao meu nada lavado de chuva a dor concede o encantamento. 
Noite

o ar da chuva

inspira.

Da janela

vejo a pedra leve

de véus de luz.

entre

os ramos da noite.

- Boa noite.

- Dorme bem.

Incessante

forma do passado.

Tantos passos

e dança por um dia.

Quantos passos,

dança e guerra

por um dia

escuro de sol?

Ó noite

de centelha e frio,

dai-nos o hábito

da paz.

Eutomia, Recife, 26(1): 380- 410, Dez. 2020 
Janelas acesas nos ramos da madrugada.

No meu quarto polvilhado de cinzas um trinado, um grão esplêndido de sol dissipa o véu dos meus olhos, o chiado dos meus ouvidos.

Infinitas luas de vapor de sódio, ao canto um ramo é o bastante.

Nada vence a folha nova, a semente de luz.

Ao canto basta o desprendimento.

Minha lanterna incendeia um céu seco de estrelas. 
A quem chegarão estas folhas a desdobrarem-se extrato do incerto grão?

Dedicado ao ofício do momento, mãos densas do sol da noite, sexo ébrio de mosto, jogo lúdico à espreita da incompletude inseparável minha e sua a quem o ofício da palavra? Só a troca (amor) nos pertence. 
Depois de recontar os segundos

de um minuto

de silêncio, luz de primavera é o paraíso.

Chuva de primavera frutifica a seca enraizada de inverno.

Cada artéria prima na geração da flor.

Pássaros e sóis da noite

renovam

brotos e botões.

i Ricardo Carranza. Arquiteto e urbanista pela Universidade Presbiteriana Mackenzie (1992), tem mestrado em Arquitetura e Urbanismo pela USP (2000) e é professor titular III do Centro Universitário Belas Artes de São Paulo. Filiado à UBE. Editor da revista eletrônica 5\% arquitetura+arte ISSN 1808-1142 desde 2005. 